\title{
Analysis of Village Fund Supervision in Gampong Geulumpang Tujoh, Matangkuli District (Study at the Inspectorate of North Aceh Regency)
}

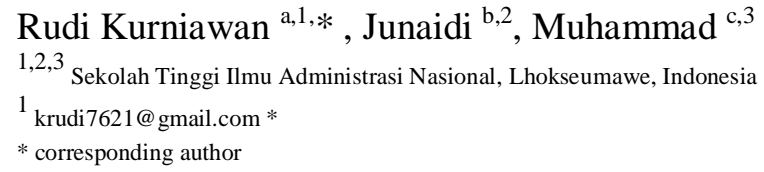

ARTICLE INFO

\section{Article history}

Received 2020-11-10

Revised 2020-12-22

Accepted 2020-12-30

Keywords

Analysis, Supervision, Village Fund

\begin{abstract}
Supervision of village funds is an action in the management of village funds carried out by government officials. This is because village funds are funds sourced from the State Revenue and Expenditure Budget intended for villages through the Regency / City Regional Revenue and Expenditure Budget and are used to finance government administration, development and community and community empowerment. The purpose of this study was to determine the supervision of village funds carried out by the Inspectorate at Gampong Geulumpang Tujoh, North Aceh Regency. The type of research is using a qualitative approach. Data analysis used data reduction, data presentation and drawing conclusions or verification. The results of this study were the supervision of village funds carried out by the Inspectorate at Gampong Geulumpang Tujoh, Matangkuli District, North Aceh Regency, carried out in several stages, namely inherent supervision, functional supervision, legislative supervision and community supervision and the obstacles faced by the inspectorate in monitoring village funds in Gampong. Geulumpang Tujoh, Matangkuli District, North Aceh Regency, is that there is no element of accuracy of village funds, is not timely in providing village fund information and is not objective in managing village funds. It is hoped that the obstacles in the supervision of village funds carried out by the Inspectorate of North Aceh Regency should require a special budget provided by the central government to further support the implementation of supervision of village funds carried out by the North Aceh District inspectorate, besides that the North Aceh Inspectorate needs to add members to each supervisory team so that the inspection can run thoroughly.
\end{abstract}

\section{INTRODUCTING}

Regional Autonomy is the authority possessed by an autonomous region to regulate and manage its people based on the aspirations of the community, in accordance with applicable laws and regulations. In order to carry out regional autonomy, it is necessary to make further regulations from the law. For a village, the autonomy that is owned is different from the autonomy that is owned by the province, regency and municipal areas. The autonomy that a village has is based on its origins and customs, not based on the transfer of authority from the government. The village is a legal community unit that has the authority to regulate and manage the interests of the local community based on local origins and customs which are recognized in the national government system and are located in the district area. Governmental affairs based on village origins, the affairs which fall under the authority of regency government are delegated to the village.

The supervisory role is assumed by the Regional Supervisory Agency (Bawasda). Bawasda has the task of carrying out functional supervision of the implementation of Regional Government. From the tasks that are carried out, it can be seen that Bawasda has a strategic task to realize good governance within the Government. In addition, referring to the duties carried out by the Bawasda, the role of the organization in the form of this body is expected to ensure the realization of good governance on the objects of its examination.

The regulations governing the implementation of supervision in the regions are dynamic. However, among those rules are Law Number 23 of 2014 concerning Regional Government, 
Government Regulation Number 20 of 2001 concerning Guidance and Supervision of the Implementation of Regional Government. In addition, there is also a Presidential Decree No 74 of 2001 concerning Procedures for Supervision of Regional Government Administration and a Decree of the Minister of Home Affairs No 67 of 2007 concerning the Distribution of Village Development Programs.

Supervision is very influential in assisting the government's efforts to achieve good governance. So far, the implementation of guidance and supervision still faces various obstacles, including lack of support from human resources, adequate funding sources, weak internal control and lack of commitment from direct superiors. Supervision is one of the important elements in response to performance appraisal of the demands for accountability of public sector organizations for the realization of good governance. Supervision functions to help achieve the goals set by the organization and plays a role in early detection of irregularities in implementation, abuse of authority, waste and leakage.

The phenomenon that occurs is known that North Aceh Regency is one of the autonomous regions of the regional government that seeks to provide the best possible service to the community, especially in the implementation of regional development to the village, in this development of course it is related to finance or funds given from the center to regions, to maximize the management of these finances or funds, the government carries out supervision by the Regional Supervisory Agency (BAWASDA) which is carried out by the Inspectorate of North Aceh Regency. Supervision of the implementation of village governance is a process of activities aimed at ensuring that the village government runs efficiently and effectively in accordance with the plans and provisions of regulations In accordance with article 4 letter (d) Permendagri Number 71 of 2015 that supervision is carried out by Government Supervisory Officials at the District Inspectorate.

The function of Supervision carried out by the inspectorate of the provincial area has the function of examining every element and or agency within the district / city government covering the fields of socio-political development, general government development, village government fostering, regional autonomy development, development, village development, administration, organization management, staffing, finance, testing and evaluation of the results of periodic reports, investigating the correctness of reports or complaints about barriers to deviation or abuse including village development because the development is financed from the state revenue and expenditure budget, from the budget and expenditure the funds are diverted to development village, there must be a supervisory agency so that the development runs according to the proposed plan and budget, as well as this supervision to avoid corrupt practices or misuse of village funds.

One of the rational reasons why there is a need for village funds is that it is in line with the regional autonomy agenda, where villages are placed as the basis for decentralization. Village funds are very relevant to the perspective that places the village as the basis for participation. Because the village is dealing directly with the community and community control is stronger. Most of the Indonesian people live in rural communities. So that decentralization at the village level will improve government functions according to the needs of the community.

Starting from this sense of concern, various programs have sprung up every year, both from the central government and local governments, which aim to encourage and raise the capacity of the community, especially rural communities. This is a form of empowerment that needs to bring back the values, local wisdom and social capital that have long been embraced by our ancestors who lived in rural areas in "mutual cooperation" which are now beginning to be eroded. The most effective and faster direction of empowering gampong communities to achieve goals is to involve the community and government elements who do have a more reactive development policy giving priority to the needs of the gampong community in budget allocation so that they are able to take advantage of the potential of their respective regions.

One of the series of empowerment programs is the provision of village funds which is a form of fulfillment of deas rights to carry out village autonomy so that it grows and develops following the growth of the village itself based on diversity, participation, genuine autonomy, democratization and community empowerment. gampong funds are funds sourced from the district APBD which are allocated with the aim of equal distribution of financial capacity between gampongs to fund village needs in the context of administering governance and implementing development and community 
services. Village funds are obtained from the gampong's financial share from the district which is distributed through the Village Treasury. Village funds are part of the Central and Regional Financial Balance funds received by the District.

Based on preliminary observations made by researchers, it is known that as many as 79 villages out of 852 villages in North Aceh District have not yet disbursed village funds. In details, 76 villages have not disbursed the second phase of funds in 2018 and 3 villages have not even disbursed the first and second phase village funds until September 2018. Funds can be disbursed if the accountability report has been submitted to the Regional Financial Management Agency. North Aceh District received village funds amounting to Rp. 661.6 billion, sourced from the State Budget of Rp. 562.2 billion and from the Government of North Aceh Regency as much as Rp. 99.3 billion. Village funds are disbursed for a year in three stages, namely the first stage of 20 percent, the second stage 40 percent and the third stage 40 percent. Some pro-active villages have entered stage three disbursement. Each village received a fund of Rp. 600 million to Rp 700 million and the head of the sub-district should be pro-active in helping village officials in his territory to make accountability reports and control the realization of development (Masriadi, 2018).

Apart from the issue of disbursement of funds, Geuchik officers in North Aceh District misused village funds, as happened in Gampong Geulumpang Tujoh, Matang Kuli District, North Aceh Regency. Regarding the case of signature forgery on the approval and improvement of the village development budget in 2017. The signature falsification was for the disbursement of village funds last year amounting to Rp. 863 million in three disbursement stages. The problems that occur in North Aceh Regency, especially in Gampong Tujoh, Matangkuli District, North Aceh Regency are due to the lack of supervision carried out by the government in managing village funds, so further attention is needed regarding village funds in North Aceh Regency (Masriadi, 2018).

\section{LITERATURE REVIEW}

\section{Analysis}

According to (Sugiyono, 2015) says that analysis is an activity to look for a pattern besides analysis is a way of thinking related to systematic testing of something to determine parts, relationships between parts and their relationship to the whole. Analysis is an attempt to break down a problem or focus of study into parts (decomposition) so that the arrangement of the form of something that is parsed is clearly visible and therefore its meaning can be more clearly understood or the situation is more clearly understood. (Sugiyono, 2015) also explains that analysis is difficult work, it requires hard work. There is no specific way in which to conduct the analysis, so each researcher must find his own method which he feels is appropriate to the nature of the research. The same material can be classified differently. So it can be concluded that the analysis is the decomposition of a subject systematically in determining the parts, the relationships between the parts and the overall relationship to obtain proper understanding and understanding.

\section{Supervision}

Supervision is one of the functions in the management of an organization. Supervision is the process of determining performance measures and taking actions that can support the achievement of the expected results in accordance with the predetermined performance. Supervision to ensure that all activities carried out are in accordance with what has been planned, which means a process of monitoring and evaluating an activity. Thus, supervision is a process in determining performance measures in taking action that can support the achievement of the expected results in accordance with the predetermined measures (Sule \& Saefullah, 2014).

According to (Harahap, 2004) suggests that several characteristics of effective supervision are as follows:

a. Supervision must be understood its nature and use, therefore it must be communicated. Each activity requires a certain control system that is different from the supervision system for other activities. The supervisory system for sales and the system for finance will be different. Therefore the supervision system must be able to reflect the characteristics and needs of the activities that must be monitored. Supervision in the field of sales is generally focused on the quantity of sales, 
while supervision in the field of finance is concerned with the receipt and use of funds.

b. Supervision must follow the pattern adopted by the organization, the focus of supervision actually revolves around humans, because it is humans who carry out activities in the business entity or organization concerned. Employees are an internal aspect of a company whose activities are reflected in an organizational pattern, so a supervisory system must be able to fulfill principles based on organizational patterns. This means that with a monitoring system, irregularities that occur can be shown to the organization concerned.

c. Supervision must be able to identify organizational problems, the main purpose of supervision is to make what is planned into reality. Therefore, in order for the supervisory system to be truly effective, meaning that it can realize its objectives, a supervisory system must at least be able to immediately identify errors that occur in the organization. With the identification of problems or irregularities, the organization can immediately find solutions so that the overall operational activities can actually or approach what was planned beforehand.

d. Supervision must be flexible, a control system is effective, when the control system meets the principle of flexibility. This means that the supervision can still be used, even though there are unexpected changes to the plan.

e. Control must be economic. The economic nature of a control system is really necessary. There is no point in setting up an expensive surveillance system, if the objective of the surveillance can be reflected in a cheaper surveillance system. The supervisory system adopted by large companies does not need to be emulated if it is not economical for another company. The thing that needs to be guided is how to set up a supervisory system by realizing economic motives. Effective supervision depends on the situation and conditions at hand. There is no one-size-fits-all surveillance system and all companies.

According to(Maringan, 2004), the objectives of supervision are as follows:

a. Prevent and correct errors, deviations, mismatches in the implementation of the tasks performed.

b. So that the implementation is carried out in accordance with a predetermined plan.

The company's goal can be achieved, if the supervisory function is carried out before the occurrence of deviations so that it is more preventive (prefentive control). Compared to monitoring measures after irregularities occur, the objective of supervision is to keep the results of implementing activities in accordance with the plan. The stipulated provisions and infrastructure are actually implemented. Because good supervision will create effective and efficient company goals.

According to (Herujito, 2001) The types of supervision can be viewed from three, namely in terms of time, object and subject.

1. Supervision in terms of time is supervision that can be carried out both in a preventive and repressive manner. The tools used for monitoring are planning and budgeting. Meanwhile, repressive supervision uses budget tools and reports.

2. Oversight in terms of objects is supervision of production, finances, employee activities and so on. Oversight in terms of object is also administrative supervision and operational supervision.

3. Supervision in terms of subject is supervision consisting of internal control (supervision carried out by the party concerned) and external supervision (supervision carried out by parties outside the organization)

\section{Village Fund}

The Village Fund is a fund sourced from the State Revenue and Expenditure Budget intended for Villages which is transferred through the Regional Revenue and Expenditure Budget. Regency and is used to finance governance, development implementation, community development, and community empowerment. The provisions governing the Village Fund are Government Regulation Number 60 of 2014 concerning Village Funds sourced from the State Revenue and Expenditure Budget as the implementation of the provisions of Article 72 paragraph (1) letter b and paragraph (2) of Law Number 6 of 2014 concerning Villages.

Allocation of the Village Fund is calculated based on the number of villages and is allocated with due regard to the population, poverty rate, area size, and geographic difficulty level. In Government Regulation Number 60 of 2014 Article 11 paragraph (3) regulates the weight for the total population of $30 \%$, area of $20 \%$ and the poverty rate of $50 \%$ and is multiplied by the District Construction Expensive 
Index. The data used is the source of data from the calculation of the General Fund Allocation (DAU). Then the Government Regulation was revised with details for the total population weighing $25 \%$, area $10 \%$, the poverty rate $35 \%$ and the Geographical Difficulty Index of 30\%. (Astuti \& Yulianto, 2016)

\section{METHOD}

This research uses a descriptive qualitative approach. According to Moleong (2010: 3), a qualitative approach is an approach that seeks to interpret the meaning of an event as an interaction of human behavior in a situation. The qualitative approach was chosen because it will facilitate the data to be obtained in depth.

\section{Research Informants}

An informant as a data source is considered capable of answering a defined problem on purpose, which is determined based on the consideration of the criteria, social status, economic status and position of the informant, such as the Head of the Inspectorate, Functional Inspectorate, and Gampong officials.

Method of collecting data

To obtain complete and accurate data and information, the data collection methods used in this study are:

1. Observation is one of the data collection techniques carried out through direct observation, namely data collection through observation and recording of symptoms on objects that are carried out directly at the scene. Thus, observation means observation and is an activity carried out by researchers in a study of a process or object with the intention of feeling and then understanding the knowledge of a phenomenon based on previously known knowledge and ideas. Through observation, researchers get the information needed to continue a research.(Silalahi, 2006)

2. An interview is a conversation between two or more people and takes place between the source and the interviewer. The purpose of the interview is to obtain information in which the researcher submits questions to be answered by the interviewee. Interviews can be a tool when conducted by researchers or ordinary people who are finding out about someone's personality or looking for information. As for the form of questions such as "What forms of supervision does the Inspectorate carry out against village funds".(D. M. A. Mulyana, 2013)

3. Documentation analysis.

Documentation analysis is a literature study, which receives secondary data.(Sugiyono, 2015)

Data analysis method

Data analysis techniques are very important in research. The primary and secondary data obtained were analyzed qualitatively to obtain the results of interviews that were presented to support the analysis. Data analysis is used to solve research problems from the start to the completion of data collection.

The research process, which uses an interactive analysis model according to Moleong (2010: 5), consists of four stages of data collection, namely Data Collection, Data Reduction, Data Presentation and Conclusion Drawing or Verification.

\section{RESULTS AND DISCUSSION}

\section{Village Fund Supervision Conducted by the Inspectorate in Gampong Geulumpang Tujoh, Matangkuli District, North Aceh Regency.}

Supervision is the process of determining performance measures in taking action that can determine performance measures in taking actions that can support the achievement of expected results according to predetermined measures. Supervision of village funds carried out in this study was carried out in several stages, namely embedded supervision, functional supervision, legislative supervision and community supervision.

\section{Onboard Supervision}

Inherent supervision is carried out by the Inspectorate of North Aceh Regency in accordance with 
the direction of superiors and procedures from the service, attached supervision is carried out in a preventive and repressive manner so that no mistakes occur when monitoring village funds in Gampong Geulumpang Tujoh, North Aceh Regency

\section{Functional Supervision}

Functional supervision is carried out by officers of the North Aceh District Inspectorate so that village funds are not misused and follow the village budget plan, the government provides village funds to each area with the aim that village development runs well and is more advanced

\section{Legislative Oversight}

Supervision of village funds is not only carried out by the Inspectorate of North Aceh Regency, the House of Representatives also supervises village funds, this is done so that village funds provided by the government have clear objectives in accordance with the village development budget plan

\section{Community Oversight}

Community supervision also plays an important role in managing village funds, it is known from the results of community supervision research conducted by village officials and other communities by conducting deliberations on the use of funds for village development and improving the community's economy

The role of the North Aceh regency ispectorate as an internal government supervisory apparatus, as an internal government supervisory apparatus the regional inspectorate has a very strategic role and position both in terms of management functions and in terms of achieving the vision and mission as well as government programs and one of them is carrying out supervision of village funds.

\section{The obstacles faced by the Inspectorate in Supervising Village Funds in Gampong Geulumpang Tujoh, Matangkuli District, North Aceh Regency are:}

Supervision of village funds has been carried out well by the Inspectorate, the House of Representatives and from the community itself. However, it cannot be avoided that when monitoring village funds, there are often obstacles faced by the Inspectorate of North Aceh Regency, including the absence of an element of accurate village fund information, not being timely in providing information on village funds and village officials who are not objective in providing reports on the results of audits of the government.

\section{Absence of Elements of Accurate Village Fund Information}

Village fund information is included in the object of inspection of the annual supervision work program, but in the inspection of village funds it does not run properly due to a lack of time and personnel, besides that the lack of facilities and infrastructure in supervision becomes an obstacle in providing accurate village fund information to the North Aceh Regency government

2. Not Timely in Providing Village Fund Information.

It is known that village officials are often not punctual in providing information on village funds due to difficulties in coordinating with village officials due to poor communication networks in Gampong Geulumpang Tujoh, North Aceh Regency. This has become a separate obstacle for village officials in providing information on village funds to the supervisory officer of the North Aceh District Inspectorate

\section{Not Objective in Managing Village Funds}

It was not objective when supervising village funds was carried out by the Inspectorate of North Aceh Regency due to time constraints and remote village locations so that there were often delays in informing the use of village funds, besides that village officials did not understand the completion of village fund reports so that Inspectorate officers had to carry out repeated consultations. repeated resulting in a follow-up to the results of the inspection of village funds. 
The supervision of village funds carried out by the Inspectorate of North Aceh Regency in Gampong Geulumpang Tujoh, North Aceh Regency is not yet effective because the data that should be used as material for inspection or comparison with the realities in the field have not been obtained by the inspection team at the time of conducting the inspection making it difficult the examination team to examine the data and draw conclusions on the results of the examination. The data inaccuracies will also cause the examiner to be unable to provide assurance that the report prepared has credibility and meets the elements of reliability.

The results of research conducted by (Wibisono, 2017) show that the weakness of supervision is due to the malfunctioning role of village assistants, weak elements of guidance and supervision from the Head of the Sub-District, Weak elements of development and supervision by the Government and Development Security Supervision Team (TP4), weak supervision by BPD, weak community participation in supervision of Village Funds, high non-budgetary costs, and inadequate human resource (HR) managers of Village Funds and Village Heads. And this is different from the results of the research that I did, the weakness of the assessment is due to the absence of accurate village fund information, the lack of coordination between village officials.

In the implementation of regulations in the village fund supervision system, it is not working and when seen in the research conducted by (Kurniawan et al., 2020) regarding the implementation of regulations it is also not working, such as a lack of human and financial resources. This is also in accordance with other research conducted by (Muhammad \& Kurniawan, 2020)

\section{CONCLUSIONS}

Based on the results of research and discussion in previous chapters and the views of respondents, the following conclusions are drawn in this chapter:

1. Efforts to supervise village funds carried out by the Inspectorate in Gampong Tujoh, Matangkuli District, North Aceh Regency are carried out in several stages, namely embedded supervision, functional supervision, legislative supervision and community supervision.

2. Obstacles faced by the inspectorate in supervising village funds in Gampong Geulumpang Tujoh, Matangkuli Subdistrict, North Aceh Regency, is the absence of an element of accurate village fund information, not being timely in providing village fund information and not being objective in managing village funds.

\section{RECOMMENDATIONS}

1. It is hoped that the supervision of village funds carried out by the Inspectorate of North Aceh Regency in the embedded supervision stage should the Inspectorate collect data 3 times a year or be carried out once every 4 months. Judging from the functional supervision should have carried out a physical examination of the use of village funds, this result can be demonstrated by following up on all reports submitted to the inspectorate regarding the use of village funds and conducting an inspection of village funds on developments that use the village fund budget as a whole. Judging from the legislative supervision, supervision of village funds is not only carried out by the Inspectorate, but the government provides policies to cooperate with other government agencies such as the DPR and the Regional Financial Management Agency of North Aceh Regency. Meanwhile, community supervision should not only be carried out by Geuchik alone, but should also involve peutuha peuet and community leaders in managing village funds.

2. It is hoped that the obstacles in the supervision of village funds carried out by the Inspectorate of North Aceh Regency should require a special budget provided by the central government to further support the implementation of supervision of village funds carried out by the inspectorate of North Aceh Regency, besides that the North Aceh Inspectorate needs to add members of each supervisory team so that the inspection can run thoroughly

\section{REFERENCES}

Anggito, A., \& Setiawan, J. (2018). Metodologi penelitian kualitatif. CV Jejak (Jejak Publisher). 
Astuti, T. P., \& Yulianto, Y. (2016). Good Governance Pengelolaan Keuangan Desa Menyongsong Berlakunya Undang-Undang No. 6 Tahun 2014. Berkala Akuntansi Dan Keuangan Indonesia, 1(1).

Harahap, S. S. (2004). Sistem Pengawasan Manajemen. Penerbit Pustaka Quantum.

Herujito, Y. M. (2001). Dasar-dasar manajemen. Jakarta: PT Gramedia.

Kurniawan, R., Rasyidin, R., Muhammad, M., \& Aruni, F. (2020). Upaya Pemerintah dalam Menerapkan Peraturan Pemerintah No. 49 Tahun 2018 Tentang Pegawai Pemerintah Dengan Perjanjian Kerja (P3K) dI Kabupaten Aceh Utara. Jurnal Public Policy, 6(1), 41-44.

Maringan, M. S. (2004). Dasar-Dasar Administrasi dan Manajemen. Jakarta: Ghalia Indonesia.

Muhammad, M., \& Kurniawan, R. (2020). BUMG Yang Mensejahterakan, Antara Peluang Dan Tantangan (Studi Dilingkungan Pemerintah Kota Lhoksuemawe). Jurnal Reformasi Administrasi: Jurnal Ilmiah Untuk Mewujudkan Masyarakat Madani, 7(2), 96-106.

Mulyana, D. (2008). Metode penelitian kualitatif: Paradigma baru ilmu komunikasi dan ilmu sosial lainnya. Bandung: Remaja Rosdakarya.

Mulyana, D. M. A. (2013). Metode penelitian komunikasi: Contoh-contoh penelitian kualitatif dengan pendekatan praktis. PT Remaja Rosdakarya.

Silalahi, U. (2006). Metode penelitian sosial. Unpar press.

Sugiyono, S. (2015). Metode penelitian pendidikan pendekatan kuantitatif, dan R\&D. Alfabeta Bandung.

Sule, E. T., \& Saefullah, K. (2014). Pengantar Manajemen Edisi ke 18. Bandung: Penerbit Prenadamedia Group.

Wibisono, N. (2017). Mengungkap fenomena pengawasan publik terhadap dana desa di Kabupaten Madiun. Jurnal AKSI (Akuntansi Dan Sistem Informasi), 2(2), 8-19. 